POISON ARROWS 
THIS PAGE INTENTIONALLY LEFT BLANK 


\section{POISON ARROWS}

North American Indian Hunting and Warfare

By David E. Jones 
Copyright (C) 2007 by the University of Texas Press All rights reserved

Printed in the United States of America

First edition, 2007

Requests for permission to reproduce material from this work should be sent to:

Permissions

University of Texas Press

P.O. Box 78 I9

Austin, TX 78713-78 I9

www.utexas.edu/utpress/about/bpermission.html

(2) The paper used in this book meets the minimum requirements of ANSI / NIS O Z39.48-I992 (RI997) (Permanence of Paper).

Library of Congress Cataloging-in-Publication Data

Jones, David E.

Poison arrows : North American Indian hunting and warfare / by David E. Jones — Ist ed.

p. $\quad \mathrm{cm}$.

Includes bibliographical references and index.

ISBN-I 3: 978-O-292-7I428-I (cl. : alk. paper)

ISBN-IO: O-292-7I $428-9$

I. Indian weapons-North America. 2. Indians of North America - Ethnobotany. 3. Indians of North America-Hunting. 4. Arrow poisonsNorth America. 5. Poisonous plants-North

America. 6. Poisonous animals - North America.

7. Neurotoxic agents-North America. I. Title. E98.A65J65 2006

$355.8^{\prime} 2-\mathrm{dc} 22$ 